\title{
Accretion Profile of the Rosy Barb, Puntius Conchonius (Hamilton- Buchanan, 1822) From the Water Bodies of Nagaland, India.
}

\author{
Amenla And S.C.Dey \\ Department of Zoology, Gauhati University Guwahati 781014, India
}

\begin{abstract}
Present study was made on 50 freshwater wild Puntius conchonius (Hamilton - Buchanan) of various sizes ranging from a total length of $5.2 \mathrm{~cm}$ to $7.6 \mathrm{~cm}$ and weighing $1.6 \mathrm{gm}$ to $7.1 \mathrm{gm}$. They were sampled from different lentic and lotic water bodies of Nagaland, to investigate the weight-length relationship. Each fish was measured and weight was taken. Log transformed regressions were used to test the growth trend. It was observed that growth in weight is not proportional to the cube of its length. Coefficient of correlation values for both male and female as well as for mixed population were found to be highly significant.
\end{abstract}

Key Words : Puntius conchonius, weight-length relationship, predictive equations.

\section{Introduction}

Puntius conchonius (Hamilton - Buchanan, 1822), also commonly called as the rosy barb, belonging to the family Cyprinidae and sub - family Cyprininae is a small fish with a moderately elongated deep and compressed body having a pointed head with small lips. In life condition it purports shinningolive green back, with flanks and belly silvery tinged. A prominent slightly oscillated black golden yellow-bordered blotch on the caudal peduncle. During breeding conditions the male changes to a lively iridescent blushing pink. This hardy and docile minnow is most impressively coloured during the mating period. Puntius conchonius (Hamilton Buchanan, 1822) is a common fish found in the pools, ditches and streams and is abundantly distributed in India, Pakistan, Srilanka, Bangladesh, Myanmar and Nepal. It has got immense importance in ornamental fisheries and is relished as a food item by the people of low-income groups.

The present study on the weight-length relationship is important for the studies on biology, population and management of the species and their fisheries (Le Cren 1951, Shafi and Quddus 1974).The significance of the studies in fishes is to assess the growth of fishes in different environment (Salam et al 1993). The growth in animal is considered in terms of increase in volume. The volume is represented by weight, which is related to the cube of linear dimensions. It is therefore, true that a relationship exists between length (linear dimension) and weight in animal (Kellicot, 1908). According to Wootton, (1990) measurement of growth as length quantify axial growth, measurement as weight quantify growth in bulk. These two categories of growth are highly correlated. A fish can change its weight without changing in length or vice versa. The relationship between weight and length for fish of a given population can be analysed either by measuring weight and length of the same fish throughout their life or of a sample fish taken at a particular time.

\section{Materials And Methods}

Live fish specimens of Puntius conchonius (Hamilton - Buchanan) were collected from the rivers and streams of Dhansiri and lotic water bodies of Dimapur District, Nagaland, during the month of May to August, 2008. Fishes were selected at random and were preserved in $8 \%$ formalin solution. They were subsequently dried for 30 seconds to 1 minute in the folds of a blotting paper and then measured by a meter scale and weighed on a sensitive balance. All the datas retrieved from the field, camp laboratory and Experimental Fishery Station, Department of Fisheries, Govt. Of Nagaland established at Dimapur, encompassing the present investigations were studied, computed and analysed in the Industrial Fishery Laboratory, Department of Zoology, Gauhati University. Bio statistical tables were used throughout the study for the calculation of various factors necessary for the expression of length - weight relationship. Length is used as type and weight as the array. The equation adopted is that of the general parabola: $\mathrm{W}=\mathrm{CL}^{\mathrm{n}}$ (Le Cren 1951). This equation when expressed in logarithmic form becomes $\log \mathrm{W}=\log \mathrm{c}+\mathrm{n} \log \mathrm{L}$, where $\mathrm{W}=$ total weight $(\mathrm{gm})$ of the fish; $\mathrm{L}=$ total length $(\mathrm{cm})$ of the fish; $\mathrm{c}=$ proportionality constant; $\mathrm{n}=$ exponential value or regression co-efficient, which when graphically represented assumes a linear form. The value of $\mathbf{c}$ and $\mathbf{n}$ are determined empirically by the following formulae, 


\begin{tabular}{|c|c|}
\hline $\log c=$ & $\begin{array}{c}\sum \log \mathrm{W} \cdot \sum(\log 1)^{2}-\sum \log \mathrm{L} \cdot \sum(\log \mathrm{L} \cdot \log \mathrm{W}) \\
\mathrm{N} \cdot \sum(\log 1)^{2}-\left(\sum \log 1\right)^{2}\end{array}$ \\
\hline And $\mathbf{n}=$ & $\frac{\sum \log W-N \cdot \log c}{\sum \log L}$ \\
\hline
\end{tabular}

The length - weight relationship in the study species has been estimated for mixed population (male and female combined), and male and female separately.

\section{Results And Discussion}

Length - weight relationship in mixed population of Puntius conchonius (Hamilton - Buchanan)

The data of mixed population consists of measurements of 20 specimens ranging in total length (TL) from $5.2 \mathrm{~cm}$ to $7.6 \mathrm{~cm}$ and in weight from 1.6 to $7.1 \mathrm{gm}$. The formula correlating the length and weight of the fish has been found to be,

$$
\text { Weight }=-2.491 \times \text { Length }{ }^{2.430}
$$

The logarithmic form of the above equation is

$$
\text { Log weight }=0.396+2.430 \text { log length }
$$

The coefficients of correlation between log length and log weight is +0.976 and the standard error of estimate in terms of logs is \pm 0.01

The test of significance of the relationship, t-test is performed, and the correlation between log length and $\log$ weight is found significant at $5 \%$ probability level.

$$
\mathrm{r}=+0.976 \pm 0.01, \mathrm{P}<0.05
$$

\section{Length - weight relationship in male population of Puntius conchonius (Hamilton - Buchanan)}

The data of male population consists of measurements of 15 specimens ranging in total length (TL) from $5.2 \mathrm{~cm}$ to $7.5 \mathrm{~cm}$ and in weight from 1.6 to $6.5 \mathrm{gm}$. The formula correlating the length and weight of the fish has been found to be,

$$
\text { Weight }=-2.188 \times \text { Length }^{2.174}
$$

The logarithmic form of the above equation is

Log weight $=0.340+2.174 \log$ length

The coefficients of correlation between log length and log weight is +0.971 and the standard error of estimate in terms of logs is \pm 0.01

The test of significance of the relationship, t-test is performed, and the correlation between log length and $\log$ weight is found significant at $5 \%$ probability level.

$$
\mathrm{r}=+0.971 \pm 0.01, \mathrm{P}<0.05
$$

\section{Length-weight relationship in female population of Puntius conchonius (Hamilton - Buchanan)}

The data of female population consists of measurements of 15 specimens ranging in total length (TL) from $5.5 \mathrm{~cm}$ to $7.5 \mathrm{~cm}$ and in weight from 2.0 to $6.3 \mathrm{gm}$. The formula correlating the length and weight of the fish has been found to be,

$$
\text { Weight }=-2.136 \times \text { Length }^{2.008}
$$

The logarithmic form of the above equation is

$$
\text { Log weight }=0.329+2.008 \text { log length }
$$

The coefficients of correlation between log length and $\log$ weight is +0.972 and the standard error of estimate in terms of logs is \pm 0.01

The test of significance of the relationship, t-test is performed, and the correlation between log length and $\log$ weight is found significant at $5 \%$ probability level.

$$
\mathrm{r}=+0.972 \pm 0.01, \mathrm{P}<0.05
$$

The main objective has been to derive the mathematical formulae, correlating the two variables weight and length, in a very general manner, for calculating one from the other within a range of error. In view of this a reasonable size range of the fish has been included in the study, which is wild caught, from the rivers, streams and rice fields of Nagaland. The sex factor is not reckoned as also the gonad condition and the gut contents. The material is, therefore, heterogeneous. The general fact which has been elucidated by Clark (1928), Walford (1932) and Schultz (1933) for other species has also been taken into consideration in the study under report. Pervin and Mortuza (2008) cited that, the length - weight relationship is very important for proper exploitation and management of fish species population. The economic value of fish depends upon its length weight relationship. With a view to supplement this, the present investigation was under taken and overall values of $\mathbf{c}$ and $\mathbf{n}$ of the species have been derived to understand a coherent picture on the accretion profile of the species, Puntius conchonius (Hamilton - Buchanan, 1822) hitherto remained unattended from any drainage system of Nagaland. 
Value of the regression coefficient $\mathbf{n}$ usually lies between 2.5 to 4.0 according to Hile (1936) and Martin (1949) and ideally fishes maintain the shape $\mathrm{n}=3$. The relationship between Weight (W) and Length (L) typically takes the allometric form: $\mathrm{W}=\mathrm{cL}^{\mathrm{n}}$, or in the linear form: $\log \mathrm{W}=\log \mathrm{c}+\mathrm{n} \log \mathrm{L}$, where $\mathbf{c}$ and $\mathbf{n}$ are constants estimated by regression analysis. If fishes retains the same shape, it grows isometrically and the length exponent $\mathbf{n}$ has the value $\mathrm{n}=3.0$, a value significantly larger or smaller than $\mathrm{n}=3.0$ shows allometric growth. A value less than $n=3.0$ shows that the fish becomes lighter for its length and if greater than $n=3.0$, indicates that the fish becomes heavier for its length as it grows (Bagenal and Tesh, 1978 and Ricker, 1979).

The exact relationship between length and weight differs among species of fish according to their inherited, body shape and within a species according to the condition of individual fish (Schneider et al 2000). The values in the present study for mixed population is 2.430 , in male 2.174 and in female 2.008 , showing negative allometric type of growth in all the population. The coefficient of correlation (r) between log of length and $\log$ of observed weight estimated in both overall, male and female fish population is positive and limited and the relationship is tested significant in all cases at 5\% probability level. Similar observations were also made by Subba and Ghosh, (2000) and Pawar and Mane, (2006) in case of Glyptothorax telchitta and Glossogobius giuris respectively.

In general, adult fishes follow an isometric growth (Beverton and Holt, 1957). The variation in 'n values may therefore be attributed to environmental factors, seasons, food availability, sex, life stage and other physiological factors of the test species. The results also indicated that, the condition was variable and dynamic and reflected its food availability and growth within the weeks prior to sampling. Similarly, Gokhan et al (2007) reported on some commercial fish species from the North Aegean Sea.

\section{References}

[1]. Bagenal, T. and F. W. Tesch, (1978). Age and Growth. In : Method for Assessment of Fish Production in Freshwater. (T. Bagenal). IBP Handbook, Blackwell Scientific Press, Oxford.

[2]. Berverton, R. J. H. and Holt, S. J. (1957). On the dynamics of exploited fish population. Fish. Investigation, $2: 533$.

[3]. Clark, F.N. (1928). The length-weight relationship of the California sardine, Sardina Caerulea at San Pedro Calif. Fish game, Bull. 12.

[4]. Gökhan et al (2007). Length-weight relationship of 7 fish species from the North Aegean Sea, Turkey. International J. of Natural and Engineering Sciences 1: 51-52.

[5]. Hile, R. (1936). Age and growth of cisco leucichthys artedi le Suercur in the lake of north-eastern highland. S. Bull. US. Bur. Fish 48: 211-317.

[6]. Kellicot,W. E., (1980). The growth of brain and viscera in the smooth dog fish, Mustelus canis, Am. J. Anat., 8 : $319-354$.

[7]. Le Cren, ED (1951). The length-weight relationship and seasonal cycle in gonadal weight and condition in the perch, Perca fluviatilus. J. Anim. Ecol. 20201 - 219.

[8]. Martin, W. R. (1949). The mechanics of environmental control of body form in fishes. Univ. Toronto. Stud. Biol. 58 : 1-91.

[9]. Pawar, B. A. And Mane, U. H. (2006). Length-weight relationship and relative condition factor of freshwater fish Glossogobius giuris (Ham.) from Sadatpur lake near Pravaranagar, Ahmednagar district, Maharashtra. J. Curr Sci.9 (1): 119-124.

[10]. Pervin, M. Rokshanara and Mortuza, G. M. (2008). Notes on length-weight relationship and condition factor of fresh water fish Labeo boga (Hamilton) (Cypriniformes: Cyprinidae). Univ. J. Zool. Rajshahi Univ. 27: 97-98.

[11]. Ricker, W. E., (1979). Growth Rate and Models. In : Fish Physiology, VIII (Eds. Hoar, W. S., D. J. Randall and J. R. Brett), Academic Press, London, pp : 677-743.

[12]. Salam et al (1993). Length - weight and condition factor relationship of freshwater Chinese carp, from fish hatchery Islamabad Pakistan. J. Res., 5: 45-48.

[13]. Scheider et al (2000). Length-weight relationship. Manual of fisheries survey methods II: with periodic updates. Machigan Department of Natural Resources, Fisheries Special Report. 25, Ann Arbor.

[14]. Schultz, L.P. (1933). The age and growth of Arthrinope affinis Oregonia (Jordan and Synden) and of other sub species of bay smelt along the pacific coast of the United States. Univ. Wash. Publ Biol 2 No. 3: 45-102.

[15]. Shafi, M. and Quddus, M. M. A. (1974). The length-weight relationship and condition factor in Hilsa ilisha (Hamilton) (Clupeiformes: Clupeidae). Bangladesh. J. Zool. 2 (2): 179-185.

[16]. Subba, B. R. And Ghosh, T. (2000). Length-weight relationship of a hill-stream fish, Glyptothorax telchitta (Ham.) from Saptakoshi river of Nepal. J. Ind Fish Ass. 27: 79-82.

[17]. Walford, L. A. (1932). The California barracuda, Sphyrna argentea, 1. Life history of the California barracuda. 2. A bibliography of barracuda (Sphynidae). Calif. Fish. Game, Bull., 37: 7-120.

[18]. Wootton, R. J, (1990). Ecology of Teleost Fishes. Chapman and Hall, London.

\section{Acknowledgement}

The author expresses her deep sense of gratitude to her teachers and mentors, Prof.S.C.Dey, Retd.Head of the Department of Zoology and Dr.G.C.Sarma, Curator of the Department of Botany, Gauhati University for suggesting the present study problem, erudite guidance and thoughtful suggestions provided throughout the course of the investigation. The author is grateful to the Director and subordinate officers of the Department of Fisheries, Govt. Of Nagaland for providing all possible facilities and encouragement. The author deeply appreciates and acknowledges the kind and valuable help extended by Dr.S.K.Sarmah, Department of Zoology, Gauhati College. Mention must also be made of all the colleagues and staffs of the aquarium unit at Dimapur for their kind help during the field work studies. Above all I wish to thank God and my family for their unwavering support and faith in me during the course of this study.

AMENLA 